\title{
Family (oikos) Evangelism for reaching forward caste Hindus in India ${ }^{1}$
}

\author{
D W Fowlkes \& P Verster \\ (University of the Free State)
}

\section{ABSTRACT}

\section{Family (oikos) Evangelism for reaching forward caste Hindus in India}

This article acknowledges the need for Church Planting Movements among the unreached peoples of India. Of particular concern to this study is the application of Church Planting Movement strategy to forward caste Hindus of India. It is shown that evangelizing households (family or "oikos" evangelism) is a New Testament strategy and the most appropriate strategy for reaching forward caste Hindus.It is concluded that Christian disciples remaining within Hindu culture and familial systems hold the potential for the most indigenous approach to evangelizing forward caste Hindus.

\section{INTRODUCTION}

Missionaries have frequently stated their evangelistic impact in India in triumphant terms: in 1934, Stephen Neill wrote, "In almost every corner of the country, the Christian Church has touched every stratum of society" (Neill 1934:11). Indian leaders themselves have spoken positively concerning the impact of Christianity and missionary efforts. In the early 1950's, Rajaiah D. Paul stated, “The educated Hindu has for the most part been profoundly affected by Christianity and the education he has received, perhaps in a Christian school or college" (Paul 1942:89). Actual results have been more modest and have not kept up with the explosive population growth among Hindus. Missionaries were often prejudiced against the very people they came to evangelize and this attitude continues today, even among indigenous missionaries as they deal cross culturally

1 This article is based on the Ph D thesis of Dr Dane W Fowlkes, Assistant Professor of Religion, East Texas Baptist University, USA, completed under supervision of Prof P Verster, Department of Missiology, University of the Free State. 
with other races, tribes or castes (Varnashrama ${ }^{2}$ is the Indian brand of racism).

Missionaries also struggled with host cultures, imposing Western structures on Indian Christians. Khushwant Singh observed that "many Christians continued bearing high sounding English names, their women wore a comical mixture of European and Indian dress. Their hymns translated (and) sung to outlandish tunes evoked more derision than reverence" (Singh 1992:76). Jack C. Winslow, a friend of Gandhi, wrote, "missionaries with the Gospel brought unessential Western accompaniments" (Winslow 1954:77). In addition, missionaries concentrated evangelistic efforts among the high caste, but with little success.

Becoming a Christian, especially a mission compound resident, created in effect a new Christian caste rather than transforming the castes and cultures from which the converts came (Gandhi 1941:27). All too often "in the process of preaching Christ, missionaries were involved in public ridicule of Hinduism" (Richard 1991:12). This evidenced a sense of exclusivism that held the Indian as inferior to the Western missionary; "Missionary history in India is inextricably tied to colonialism, a stigma that mars the work of Christ to this day" (Houghton 1983:246). How can this be changed?

\section{RESEARCH PROBLEM}

There are about twenty million Christians in India, with a large percentage of these drawn from tribal societies. Christians constitute $2.3 \%$ of India's total population. "When we view the task of the mission of God in India, we see that the citadel of Hinduism has not really been penetrated by the Christian church” (David 1998:2). Most evangelism is taking place today in India with teams distributing Christian literature all over the country, gospel programs being broadcast in the major languages of the country, and even a number of indigenous mission agencies involved in communicating the gospel, but for some reason the message of the Gospel is not

2 Varnaschramadharma is the official designation for the Brahminical social order consisting of various varnas or ritual classes. The four ritual classes of society are said to derive from the head (Brahmin), shoulders (Kshatriya), abdomen and thighs (Vaishya), and feet (Sudra) of the primordial man (Purusa) at the creation of the universe. 
penetrating into the minds and hearts of the followers of Sanatan Dharma (Hinduism).

Stated succinctly, the desire of this paper is to know whether or not the individualistic evangelistic and missionary dominated approaches of the past have actually hindered or aided the work of evangelism among forward caste ${ }^{3}$ Hindus. The goal of this paper is to develop a culturally appropriate approach to evangelizing forward caste Hindus for maximum effectiveness.

\section{PEOPLE MOVEMENT STRATEGIES IN INDIA}

\subsection{Pioneer studies}

The impact of people movements in mission are clear: "It has been scientifically demonstrated by renowned missionaries of our time that the church of Jesus Christ around the world grows most rapidly by multipersonal conversions in group movements rather than by individual conversions in isolation" (Kasdorf 1980:116). In the Foreword to J Waskom Pickett's, Christian Mass Movements in India, John R Mott, then chairman of the International Missionary Council, states, "The Christian mass movements in India constitute a significant phenomenon in the non-Christian world - an extensive and impressive effort for the social and religious uplift of depressed multitudes" (Pickett 1933:5).

David Garrison of the International Mission Board writes in Church Planting Movements that a Church Planting Movement is "a rapid and exponential increase of indigenous churches planting churches within a given people group or population segment" (Garrison 1999:7).

\subsection{Evangelization within homogeneous units or segments in People-Conscious Societies}

The modern missionary movement has tended to see the missionary endeavor as simply "preaching the Gospel to a lost world" - a world

3 Forward caste-The four ritual classes of Hindu society are said to derive from the head (Brahmin), shoulders (Kshatriya), abdomen and thighs (Vaishya), and feet (Sudra) of the primordial man (Purusa) at the creation of the universe. Brahmins and Kshatriyas are considered "forward castes". Others divide the classes into three: Forward Classes (higher castes), Backward Classes (middle and lower castes), and Harijans (very low castes). Dalit - A person outside the class system of Hinduism who was formerly termed as Untouchable. 
that has all too often been regarded as being broad groups or nations - without much attention being given to the distinctive nature or composition of that world to which the preaching was to be addressed. The unfortunate result in many instances was what McNee has termed "a foggy and ineffective mission policy and evangelistic effort” (McNee 1976:105). Wagner suggests that the failure to recognize the distinction between the various substructures within a society has often been a major source of both political and missionary difficulties (Wagner 1971:89).

Therefore, missionary strategy of highest impact and lasting significance gives due recognition to the nature of social composition (i.e. people groups), the significance of homogeneous segments within the overall super-structure of society, and as well as the national processes of communication and decision-making within each of the various segments. Only then may we effectively penetrate through the barriers of social and cultural resistance.

\section{EVANGELIZATION BY THE PRINCIPLE OF GROUP CONVERSION IN COMMUNAL SOCIETIES}

\subsection{Principles of the Church Planting Movement}

While the first principle of church planting movement strategy relates to recognizing people-groupings within society, the second principle concerns the pattern by which conversion takes place within such segments of society. Donald McGavran cautions that the term "group conversion" should be used guardedly because it contains for some the connotation of a leader making the initial and only genuine conversion decision, with others in the group merely following the leader without an experience of conversion of their own. It reflects back on the same problem connected with the term, "mass movement”. In response, McGavran writes: "There is no such thing as group conversion. A group has no body and no mind. It cannot decide anything whatever. The phrase "group conversion" is simply an easy, inexact description of what really happens" (McGavran 1990:302).

A third principle of people movement strategy describes the way the movement spreads from one group to another and may be termed kinship webs. Peter B. Hammond, professor of anthropology, Indiana University, observes that "in most cultures the social systems of greatest importance are based on kinship. (Hammond 1978:145-46). Bickers connects this essential element of society 
with the potential for people movements: (Bickers 1977:45). McNee has pointed out a significant truth related to people movements. He indicates that the unity and solidarity of the clan is uppermost in the minds of all its members. Though this may be a hindrance in the early introduction of Christianity into clan life, as increasing numbers of individuals make Christward decision the momentum shifts toward Christianity, motivating others to consider the Christian faith in order to maintain and enhance clan unity. Clan members do not want to be left behind and endanger solidarity (McNee 1976:72).

\subsection{Evaluation of the Church Planting Movement Strategy as compared to Traditional Mission Strategy}

According to Hans Kasdorf, "The question whether conversion is an individual or a group decision or both is a missiological one" (Kasdorf 1980:99). It should be added that is a theological one as well. The major issue at stake in people movement theory concerns the validity of the salvation experience of a person making his or her public commitment as part of a group conversion ${ }^{4}$. Is it possible for a group of people ${ }^{5}$ to make a valid commitment to the savior hood and lordship of Jesus Christ as one, or is conversion always an individual matter as Western Christians seem to think? Bickers states, "the difference between the two approaches of the one-by-one model and the group-oriented model does not lie at the point of 'conversion'. For neither school of thought would be willing to approve mass accessions into the Church where there is no evidence of a genuine saving experience, but only a superficial identification (Bickers 1977:54). Both approaches insist upon the essential factors of conversion as taught in scripture: (1) an individual recognition of guilt for sin, (2) an individual turning away from known sin in biblical repentance, and (3) an individual faith commitment to God through the person of Jesus Christ. These statements bring us to the conclusion that conversion is personal, but not individualistic.

4 i.e. a simultaneous declaration by a group of persons in some family or local social unit that they are moving together into the Christian faith and that they desire to be baptized together in community.

5 The term "group" is used in different contexts to refer to a family, a clan, a caste, a tribe, a homogenous unit in society, or an entire social subsystem. 


\section{AN ALTERNATIVE MODEL OF THE CHURCH PLANTING MOVEMENT STRATEGY}

\subsection{The group dynamic}

Whereas traditional mission strategy has focused on what has been termed an individualistic approach, the church planting movement strategy emphasizes conversion, baptism, and discipleship within the group dynamic of decision-making and communal life. Hiebert tells us, "We must adapt our methods of church planting to the way the society is organized or we will find little response to the gospel" (Hiebert 1995:158). In listing ten common factors or characteristics of church planting movements, Garrison includes communal implications of evangelism.

Unlike the predominant pattern in the West with its emphasis on individualism and personal commitment, Church Planting Movements typically rely on a much stronger family and social connection. Missionaries in CPMs have recognized this and urged new believers to follow the web of their own family relationships to draw new believers into the community of faith. In many cases.the churches come to consist of family units and are led by the family's head (Garrison 1999:37-38).

When individual converts are united in their faith for purposes of fellowship and protection from persecution, they represent a variety of cultural and societal norms. They lack the unity that comes from the extended kinship web of natural relationships. In addition, their children will be increasingly detached from the thoughts and ways of their kinship web. Hiebert is helpful at this point: "Western missionaries, reared in a culture that stresses individualism and personal choice, often misunderstand such decisions [group conversion]. Many of them as people go back and then come to Christ one by one. In doing so they say to people that this is an unimportant decision, for only minor decisions are made by individuals. Moreover, people often feel rejected by the missionary and return to their old religion” (Hiebert 1995:159).

\subsection{Characteristic effects of People Movements on Churches}

Unlike the predominant pattern in the West with its emphasis on individualism and personal commitment, Church Planting Movements typically rely on a much stronger family and social connection. Missionaries in CPMs have recognized this and urged new believers to follow the web of their own family relationships to 
draw new believers into the community of faith (see Acts 16:31-32). In many cases, the churches come to consist of family units and are led by the family's head.

What Garrison describes as a frequently seen characteristic of CPMs is better understood as part of the biblical foundation and the very fabric of multi-individual movements to Christ. This characteristic is wrapped up in the New Testament reality of oikos.

\subsection{Oikos or family evangelism}

\subsubsection{The meaning of oikos in the New Testament}

Several usages of oikos are to be noted in Scripture. According to Thayer's Greek-English Lexicon of the New Testament, oikos has three primary meanings: 1. "a house", which may mean "an inhabited house", "any building whatever", or "any dwelling place"; 2. "the inmates of a house, all the persons forming one family, a household"; 3. "stock, race, descendants of one” (Thayer 1979:441). Gerhard Kittel and Gerhard Friedrich (1974:125) discuss various aspects of oikos. In general Greek and Hellenistic usage oikos means "house" or "dwelling" and often "temple". But oikos may also mean "domestic affairs" or "possessions" as well as "family" or "family property”.

One semantic field of oikos in the New Testament relates to the idea of extended family and possessions and is usually translated, "household". Under the old Attic law, oikos was the whole estate, while oikia referred to the physical dwelling only. Later, that distinction was lost in the Greek as there are several places in the New Testament where oikia actually means "the inhabitants of a house" (Matthew 12:25). "Greco-Roman political writers understood the household to be the basic building block of the state. Cities, they observed, are composed of households" (Stambaugh and Balch 1986:123). The importance of the oikos was such that secular ethicists felt the stability of the city-state depended upon responsible management of the oikos or household.

One is unable to understand the ecclesiology of the Apostle Paul apart from noting his understanding of and emphasis upon the oikos concept. There are numerous references to the secular oikos in Paul's writings. (oikia: 1 Cor 11:22; 16:15; Phil 4:22; 1 Tim 5:13; 2 Tim 3:6; oikos: Rom 16:5; 1 Cor 1:16; 11:34; 14:35; 16:19; Col 4:15; 1 Tim 3:4, 5, 12; 5:4; 2 Tim 1:16; 4:19; Tit 1:11; Philemon 2). Some of these refer to the place in which believers met for worship. (Rom 
16:5; 1 Cor 16:9; Col 4:15; Philemon 2). As distinctions between Judaism and early Christianity became more obvious, Christians left the Temple and synagogues in favour of meeting in the homes of certain believers. Paul's subsequent references to churches (ekklēsia) are most likely to such house churches. Paul's use of household terminology conveys his thinking about God's people in relation to God and one another.

Paul's primary interest was not in the conversion of individuals, but the formation of Christian communities composed of a number of household groups meeting together occasionally. Archaeological evidence reported by J Murphy-O'Connor confirms that the average household could only have accommodated fifty with difficulty and it is more probable that believers met more regularly as subgroups in smaller numbers (in Johnston 1903:885).

\subsubsection{The role of oikos in Church Planting Movements}

\subsubsection{Oikos Evangelism}

Peter B Hammond, professor of anthropology at Indiana University, states that "in most cultures the social systems of greatest importance are based on kinship. Human beings everywhere are born into some sort of family. And almost always this family is important in giving them - literally and figuratively - a start in life: producing them, feeding, clothing, protecting, and educating them, and eventually establishing for them a 'place' in society. ... In most cultures the kin group plays an even more important role [that in America], lasting throughout life as the principal source of the individual's emotional, economic, social-and frequently supernatural-support, and providing the basis for community organization" (Hammond 1978:145-46). Another professor of anthropology, David G Mandelbaum of the University of California, observes: "Whatever diversity there may be among social groupings the world over, there are at least two types which are found in every human society. The family is one of them - in every land, among every people, the child is ordinarily raised and nurtured within a family. The other type of group universal to humanity... is the local community. Just as no person normally lives all his life alone, devoid of family, so does no family normally live entirely alone, apart from any local group” (Mandelbaum 1991:146). Mandelbaum goes on to describe a third category he calls "clans" that he considers a cultural universal. He explains that clans "are extensions of the 
local group...voluntary associations based on common interests...ranging from trade unions and medical associations to bridge clubs and parent-teacher associations. Each of these groupings is held together by a common interest, an interest arising from mutual participation in the same trades, the mutual enjoyment of a game, or mutual problems in relation to a set of children" (Mandalbaum 1991:146).

These and other experts in the field of contemporary anthropology identify three universal units of societies worldwide that are based on the following:

1. Common kinship

2. Common community

3. Common interests

The New Testament oikos, when understood as a household, corresponds to what contemporary anthropologists define as the three universal social systems of common kinship, common community, and common interests ${ }^{6}$. In fact, "this phenomenon is not only transcultural, it is transhistorical, reaching across centuries" (Wolf s.a: 1).

\subsubsection{Strategic implications for India}

Personal evangelism, as practiced and understood in the individualistic Western World, will never produce a church planting movement among the communal people groups of India, or anywhere else for that matter. Traditionally, the strength of Indian society lies in the extended or joint family. Atul Aghamkar ${ }^{7}$ quotes Raghuvir Sinha as follows: "The joint family in Indian society is altogether a different type of institution, which has evolved out of

6 See also Paul Hiebert's discussion of kinship, community, and association: Paul Hiebert, Cultural Anthropology, (Philadelphia: Lippincott, 1976): 221, 243, 257, 261, 263.

7 The Rev. Aghamkar ministered in two cities in central India with the Christian and Missionary Alliance as a church planter and pastor and now teaches fulltime at the Union Biblical Seminary in India. Dr. Atul Aghamkar is the only Indian in the country with a doctor of philosophy degree in urban missions. Atul heads the department of missions and trains pastors and future pastors, missionaries and evangelists for ministry in India and south Asia. 
cultural and ethical traditions and prerogatives"8 (Van Engen 1994:2). Although the specific expression of extended family in India may vary from place to place, normally an extended family consists of a number of married couples (relatives) and their children living together in the same household. According to Thomas and Devanandan, "A joint family is a group of people who generally live under one hearth, who hold property in common and who participate in common family worship and are related to each other as some particular type of kindred" (ibid, 2). Indians place much importance on the family because of its accompanying sense of identity and security.

The history of the church in India clearly shows that whenever individuals were encouraged to become Christians along with their oikos, people movements have taken place. "It is easily proved from history that the great advances of the Christian faith have generally occurred along the lines of natural kinship relationships" (Greenway 1992:4). Oikos evangelism that is accompanied by church planting can bring large segments of people into the church without alienating them from their kinship webs. Many Indians blame the Christian church for encouraging social disintegration in opposing the caste system and emphasizing individual conversion, and say that the strength of Hindusim is its well-integrated family system. While it is true to say that Hinduism contributes to family cohesion, the same may be said of Christian churches that are planted according to the oikos evangelism strategy.

Rajendran accepts oikos evangelism as the natural means of spreading the gospel and fostering people movements, but does express concern that it does not promote an elitist agenda. "Evangelism along people group lines appears to be the New Testament model. But one may oppose it for dividing people on caste and culture lines perpetuating Varnashrama Dharma, the elitist Hindu idea of caste. People also tend to stick together as castes even after they become Christians for several generations, which is, of course inconsistent with the picture of the Church as one body, brothers and sisters in Christ” (Rajendran 1998:74). David Sun Lim

8 See Atul Aghamkar, Family Coherence and Evangelization in Urban India, in Van Engen, Charles and Jude Tiersma (eds.) God So Loves the City: Seeking a Theology for Urban Mission. Monrovia, CA: MARC, 1994. 
advocates this as a specific approach to doing mission. He calls this method "spiritual reproduction through small groups". He argues that the best context for evangelism and outreach, discipleship and spiritual growth is the small group, where the priesthood of all believers can be realized. The small group is the locus where the servant-church model is put into practice (Van Engen 1999:168).

\section{SUGGESTIONS FOR FAMILY (OIKOS) EVANGELISM IN INDIA}

\subsection{Encourage discipleship that allows the bhakta to remain a part of Hindu culture and the familial system}

The rational for this component has been previously established. Only in remaining a vital part of one's family system will the gospel have the potential for spreading naturally and igniting a church planting movement. When individuals are extracted from their natural and God-given environment, evangelism stops and a church planting movement becomes impossible. The major difference between this approach and the traditional Western approach to evangelism and follow-up is lack of immediate connection with a larger group of disciples. This approach acknowledges Hindu emphasis on individual freedom as well as the importance of remaining within the family for immediate and future impact.

According to Scripture, the gospel is a stumbling block and offence to natural man (Rom 9:32) ${ }^{9}$. To become a disciple of Christ, one must accept the offence of the cross, the scandalon. The evangelist must not omit this and the believer cannot avoid it. But on the other hand, Scripture tells us to refrain from placing inappropriate and unnecessary stumbling blocks in the path of persons coming to Christ. In Isaiah 57:14 we read, “And it will be said, 'Build up, build up, prepare the road! Remove the obstacles out of the way of the people"' (NIV). The Apostle Paul states in Romans 14:13, "Therefore let us stop passing judgement on one another. Instead, make up your mind not to put any stumbling block or obstacle in your brother's way" (NIV). And again in 1 John 2:10 we read, "Whoever loves his brother lives in the light, and there is nothing in him to make him stumble" (NIV).

9 “As it is written: 'See, I lay in Zion a stone that causes men to stumble and a rock that makes them fall, and the one who trusts in him will never be put to shame."” (New International Version). 
In India it is made very difficult and almost impossible for the forward caste people to become Christians, by putting unscriptural offences in their way - they are compelled to join the church of a very different homogenous unit. Any forward caste person who becomes a Christian and joins an existing church is identified with the dalits and is considered dead to his or her family and his or her own community. The potential of being salt and light in one's own household is removed before it begins. The true body of Christ is casteless, but to make it as a precondition for an individual to become a disciple of the Lord Jesus Christ is unscriptural and counterproductive. "By putting undue emphasis on the caste issue, we are pleading more for social change than for spiritual conversion" (Subbamma 1970:75-76). This is an unnecessary offence we are erecting in the way of those who would come to Christ. Bishop Leslie Newbigin decried establishing social barriers of any kind for Hindus to become Christians: "I would encourage a believing Hindu to become a Christian. I will not say to him: Become one of us, a Christian like me and follow all the habits and customs you see among the people called Christians (Newbigin 1969:110).

\subsection{Evangelize naturally within one's own oikos and in this way crossover into intersecting households}

It has already been established in this paper that the oikos approach to evangelism is the most natural and most New Testament-form of evangelism, therefore, it is not necessary to restate this fact. What does need to be explained is the connection between the person of peace concept, the oikos approach to evangelism, Christian bhakti, and church planting movements.

When an individual surrenders to and acknowledges Jesus Christ as Lord and is the first to do so from his or her Hindu family, he or she is, in effect, the person of peace for that family. No outside influence is needed to reach that family of Christ as all that is needed to reach the entire oikos is the bhakti of that one new believer, lived out before the oikos in terms that are entirely familiar to them. He or she must not be attached to an existing Christian church as that would serve to immediately remove his or her influence as person of peace for that oikos. Those who would argue against this would have hundreds of years of missionary history to explain. 
The radical nature of this proposal is that Christian discipleship or bhakti is best allowed to develop naturally and indigenously when it commences and continues for a time apart from membership or participation in any existing Christian community. An essential part of Christian bhakti is to serve as salt and light as one lives out the commands and love of Jesus Christ, and this is best accomplished when the bhakta remains naturally connected to his or her Hindu family. In this way, he or she is free to function as the person of peace for that oikos and becomes the conduit for other family members to also establish diksa with the Lord Jesus Christ as sat guru.

\subsection{Realize a church is established when more than one member of a household becomes a Christ bhakta ${ }^{10}$ and they come together to fulfill the purposes of a New Testament church}

It has been pointed out that there are numerous advantages of using house churches among the caste communities of India.

1. Hindus are accustomed to this kind of fellowship and worship.

2. If the system is Christianized, they feel quite at home in it and participate easily in it.

3. This is most important for the spiritual life of members. The Word of the Lord in hymns and Bible passages gets through to them.

4. Meeting in the home avoids much of the unreality fostered by putting on special clothes to go to hear the Gospel in a "church building" in the residential quarters of an ethnic unit which they consider very different to their own.

5. Through house churches, we demonstrate Christianity in the midst of the non-Christian community. Each new house exposes a new sent of intimates and relatives (Subbammma 1970:82-83).

While this is admittedly a much better approach for reaching Hindus, especially forward caste Hindus, than the traditional Western missionary approach of extracting new believers and establishing essentially a Christian caste without any hope of widely influencing

10 The life of discipleship is also described as a life of bhakti or devotion. The individual disciple may be called a bhakta. As the disciple responds day by day to Christ's love with love of his or her own, he or she is practicing Christian bhakti. 
the Hindu community, it stops short of establishing a truly indigenous expression of Christ bhakti that leads to a Church Planting Movement. A far better approach is the natural conclusion to the discoveries of this paper, a truly indigenous expression of Christ bhakti.

When more than one member of an oikos becomes a disciple of the Lord Jesus Christ through the influence of the person of peace for that oikos (the first Christ bhakta of the oikos), the pair or small group within the family are able to fulfill the purposes of a New Testament church. While it is impossible to find commonality concerning the nature of a New Testament church, a helpful definition would be that a local church is a prophetic community of faith.

\subsection{Christian gurus ${ }^{11}$ following a pauline model will offer spiritual guidance on a regional and circuit basis}

The Apostle Paul provides the most appropriate model for leadership development for these small groups of gathered believers. Rather than a shepherd model for a local church, his is a regional guru model. Paul did stay in a few places for an extended period of time (e.g. Ephesus), but primarily his was one of missionary endeavour with connected spiritual responsibility for young churches and young church leaders. He was, for all practical purposes, the leading guru for the believers in Ephesus, Corinth, Thessalonica, Rome, etc. (Singh 2001:3-5).

Such spiritual guides will be essential in this non-traditional approach to Christian discipleship and church planting. With clusters of believers being small initially and perhaps eventually as well, Christian gurus will be required to travel some distance and be available to believers on a regional basis.

\subsection{Churches will rather not have a building, paid leadership or established programs; instead, they will rather be organic}

Although some churches in Indian history, e.g. the Church of South/North India did make good use of the building of churches, this has very often not been a productive method of evangelizing

11 Guru - The English word 'guru' has its origin in the Sanskrit term. A guru may be defined as a spiritual teacher or head of religious sect; influential teacher; revered mentor. 
Hindus. "For the mission or the existing Church to invest money in buildings in caste sections may not be a wise thing to do. Especially in pioneer projects, that money can be used for many other things which are essential for communicating the Gospel” (Subbamma 1970:84). The need for such a building-free, contextually appropriate approach to church planting will only increase in importance as opposition to evangelization continues to strengthen. "A man external obstacle for evangelization in Rajasthan, as indeed elsewhere in India, originates in fundamentalist Hindus, the Sangh Parivar, whose animosity and opposing activity have increased in proportion to the increase of their political power" (Lesser 1998:6566).

\section{CONCLUSION}

We see clearly now that the traditional approach to evangelism and church planting in India has failed and actually served to contradict its intended outcome. Missionary efforts have, in effect, produced a separate caste for Christians, thereby removing believers from their familial systems and reducing their potential for spiritual influence. 'Caste Christians' relinquish the ability of influencing their "households" (oikos), which is the normal New Testament means of propagating the gospel and making converts.

In addition, we see that Indians prefer to make decisions as a group or family, rendering the Western individualistic approach to "deciding for Christ" ineffective and counter productive. As a result, this authors propose that the best way to facilitate a church planting movement among Hindus is to refrain from planting churches. In other words, the contextually appropriate approach to evangelizing forward caste Hindus is to allow converts to remain as vital parts of their familial systems and make disciples according to accepted Hindu patterns of spiritual guidance. In time, converts will influence other family members toward Christ and, together, become a 'house church' in the truest sense of the term. This non church planting method of facilitating a church planting movement among Hindu people groups may sound contradictory, but will actually liberate from the ineffective and counter productive traditional missionary methods of the past in India and usher in the first church planting movements among forward caste Hindus in India. In so doing, we 
may actually bring about that for which Herbert Hoefer ${ }^{12}$ longs: "Can you imagine a church in India that draws on all the beauty and profundity of the ancient cultures of India? What a great contribution that would be to the great nation of India and to the worldwide Christian fellowship” (Hoefer 2004:13).

\section{Consulted literature}

Ayer, P u.p. Household Evangelism: What is Our Best Hope for Reaching a Nation that Resists Traditional Mass Evangelism?

Bickers, H May 1977. "A Missionary Strategy for Evangelism in Central Africa: an Examination of People-Movement Strategy in the HistoricalCultural Context of Malawi". Ft. Worth, Texas: Southwestern Baptist Theological Seminary.

David, G. 1998. Communicating Christ Among Hindu Peoples. Chennai, India: CBMTM Publications.

Gandhi, M. 1941. Christian Missions: Their Place in India. Ahmedabad, India: Navajivan Publishing House.

Garrison, D 1999. Church Planting Movements. Richmond, Virginia: International Mission Board.

Greenway, R 1992. Discipling the City: A Comprehensive Approach to Urban Mission; second edition. Grand Rapids, Mi.: Baker Publishing Group.

Hammond, P 1978. An Introduction to Cultural and Social Anthropology; second edition. London: MacMillan Publishing Company.

Hiebert, Paul G 1983. Cultural Anthropology. Grand Rapids Mi.: Baker.

-, 1985. Anthropological Insights for Missionaries. Grand Rapids, Mi.: Baker.

-, Meneses, E 1995. Incarnational Ministry: Planting Churches in Band, Tribal, Peasant, and Urban Societies. Grand Rapids, Mi.: Baker.

Hoefer, H 2001. Churchless Christianity. Pasadena, Ca.: William Carey Library.

-, 2004. Land of Dharma. Mission Frontiers (May-June): 10-13.

Houghton, G 1983. The Impoverishment of Dependency. Madras: CLS.

Johnston, H 1903. The Private Life of the Romans. Chicago; Scott, Foresman and Company.

Kasdorf, H 1980. Christian Conversion in Context. Scottdale, Pa.: Herald Press.

12 Herbert Hoefer is Professor of Theology at Concordia University in Portland, Oregon and USA Lutheran Church-Missouri Synod Mission Director for India and Sri Lanka. 
Kittel, G and Friedrich, G, Bromiley, G, translator. 1974. Theological Dictionary of the New Testament. Grand Rapids, Mi.: Eerdmans.

Lesser, R 1998. Evangelization in Rajasthan: Problems and Possibilities. Indian Missiological Review (December): 64-70.

McGavran, D 1990. Understanding Church Growth. Grand Rapids, Mi.: Eerdmans.

McNee, P 1976. Crucial Issues in Bangladesh: Making Missions More Effective in the Mosaic of Peoples. South Pasadena, Ca.: William Carey Library.

Mandelbaum, D 1991. Society in India. fifth edition. Berkeley, Ca.: University of California Press.

Neill, S 1934. Builders of the Indian Church. London: The Livingstone Press.

Newbigin, L. 1995. The Open Secret: An Introduction to the Theology of Mission. Grand Rapids, Mi.: Eerdmans.

-, 1974. The Gospel in a Pluralistic Society. Waco: Word Books.

Newbigin, L and Dorairaj, P (eds.) 1969. Proposed Constitution for the Churches of Christ in South India. London: Christian Literature Society.

Nida, E 1976. Customs and Cultures: Anthropology for Christian Missions. South Pasadena, California: William Carey Library.

Paul, R 1952. The Cross Over India. London: SCM Press.

Pickett, J 1933. Christian Mass Movements in India: A Study With Recommendations. New York: Abingdon Press.

Richard H 1998. Christ Bhakti: Narayan Vaman Tilak and Christian Work among Hindus. Secunderabad, India: O M Books.

Singh, K 1992. India: An Introduction. New Delhi, India: Vision Books.

-, 2001. The Satguru-Part One. Tacoma, Washington: MGL-Multilingual.

Stambaugh, J, Balch, D 1986. The New Testament in Its Social Environment. Philadelphia: Westminster Press.

Subbamma, B V 1970. New Patterns for Discipling Hindus: The Next Step in Andhra Pradesh, India. South Pasadena, Ca.: William Carey Library.

Thayer, J 1979. Greek-English Lexicon of the New Testament. Grand Rapids, Mi: Zondervan.

Van Engen, C, Thomas, N, Gallagher, R (eds). 1999. Footprints of God: A Narrative Theology of Mission. Monrovia, Ca.: MARC.

Van Engen, C, Tiersma, J (eds.) 1994. God So Loves The City. Monrovia, Ca.: MARC.

Wagner, P 1971. Frontiers in Missionary Strategy. Chicago: Moody Press. 
Winslow, J 1996. Narayan Vaman Tilak. Pune, M. S., India: Word of Life Publications.

Winslow, J 1954. The Eyelids of the Dawn. London: Hodder and Stoughton.

Wolf, T [s.a]. Oikos Evangelism: The Biblical Pattern. [s.a.] 